\title{
The message of the book Ruth: A reflection on Naomi's traumatic journey to Mara and back
}

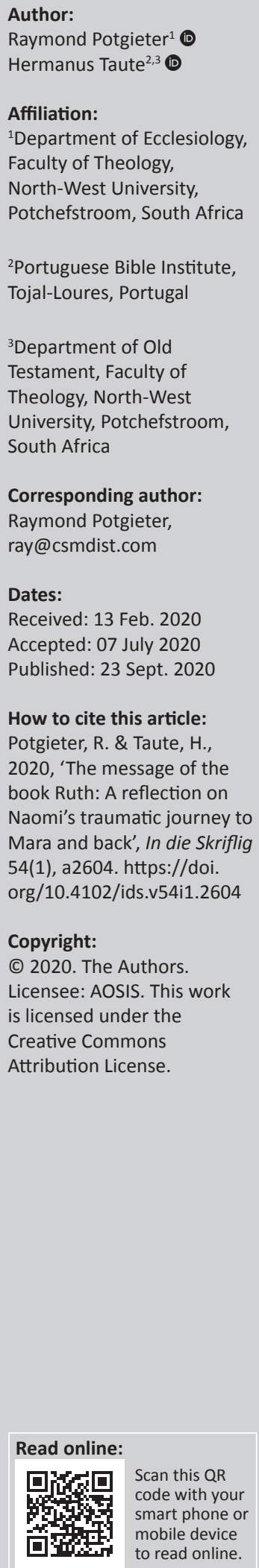

The book of Ruth is generally regarded as centring on the key figure of Ruth. It is claimed that this limits the narrative, influencing the interpretation. Several literary techniques suggest the author's intentional focus on Naomi, her faith struggles and God's gracious healing of an embittered mother. Whereas the paradigm of covenant faith and hesed [faithful love] feature prominently they do also highlight the spiritual transformation that came about for Naomi upon her return from Moab. The fullness and completed rest for Naomi continued consequentially to bear fruit for God's people through the tribe of Judah. Historically, it confirmed the royal line of David which concluded with God's Go'el [kinsman-redeemer].

Keywords: Naomi; Mara; Ruth; Boaz; Goel; Shaddai; Yahweh; chesed; David.

\section{Introduction}

Why the focus on the book of Ruth and particularly on the person and character of Naomi? It might just as well be a more esoteric focus on the distant God who finally remembers both Naomi and Ruth in their plight. Both are major characters of the unfolding human drama of the book which forms part of the Ketuvim or writings. ${ }^{1}$ Queen-Sutherland (2016:xv; James 2008:11) extrapolates it as the story of 'women and widows' from two different worlds, readily recognised thousands of years later. James (2008) broadens the horizon due to the absence of male characters:

$[N]$ ot to establish notions of female superiority as some might wish, but to give us a clear view of the women and to underscore that the story centres on them and on their relationship with God. (p. 13)

The Bible indeed 'has a lot to say on the subject of God's goodness to women' (James 2008:26). Anyone who even has a remote acquaintance with both Naomi and Ruth, will be inclined to agree with James.

Traditionally, studies on the book of Ruth focus on Ruth and on the theme of kinsman-redeemer. This article focuses on the more neglected character, Naomi, and for good reason.

It is a story set in the context of patriarchal culture in which the operation of God's care is evidentially revealed in the lives of two ordinary women. When the preferred character of Ruth features as the primary sermon illustration, it may be usefully juxtaposed with the so-called selfabsorbed Naomi. Ruth's angst as widow accompanied by poverty, let alone being a foreigner (Queen-Sutherland 2016:102), does not enjoy much attention as she ventures into the grain fields of Bethlehem.

The book of Ruth is also Naomi's story. Initially, it is an account of bitterness reminiscent of Job (James 2008:28, 37ff.), but concludes with Naomi content (cf. Rt 4:14-17a). However, the story also gently presses the reader not to conclude too much about the Naomi of the story's ending, but with the remarkable way in which the reader is guided into a more profound knowledge of God. ${ }^{2}$ This is an invitation to women and men to meet with Naomi and also with Ruth, but to conclude with a transformation by the discovery of God's love for women. ${ }^{3}$

\footnotetext{
1. The Hamesh Megillot (Five Scrolls) include Ruth, Song of Songs, Qoheleth, Lamentations and Esther. On the other hand, the Babylonian Talmud orders the Ketuvim as Ruth, Psalms, Job, Proverbs, Ecclesiastes, Song of Songs, Lamentations, Daniel, Esther, Ezra and Chronicles.

2.'In reality, however, it is a highly sophisticated religious work' (Korpel 2001:227, [italics original]). Korpel emphasises a theodictic purpose.

3.The theological purpose of Ruth is adequately explored by Korpel (2001:227-233) who explores a range of diverse opinions.
} 


\section{A brief approach to understanding how Naomi fits into the narrative structure of the book}

The skilfully written book of Ruth uses many ways to treat Naomi as a major character and for that reason it is necessary for the text to 'let her speak'. Matters such as the date of the book, whether it is a coherent composition revealing little of editing, whether the characters were historical persons and so on, have been dealt with elsewhere (Korpel 2001; also see numerous footnotes). This paragraph will give a cursory overview of some of the ways the structure of the book of Ruth ${ }^{4}$ allowed for various approaches to its understanding. See for instance Figure 1 identifying the Naomi-conversations.

Hubbard (2011:1142) describes the book as a literary gem that uses many rhetoric and literary devices like inclusions, parallels and inverted structures, and repeated keywords that account for its popularity. Chapters $1-4$ of the book Ruth reveal many intertextual links. One link often presupposing another link and so on, adequately demonstrated by Korpel (cf. 2001:218ff.) taking ancient socio-cultural traditions into account. This is diametrically opposite to traditional references such as 'a relatively simple story, a charming folktale with little theological depth' (Korpel 2001:1). The concentric structure attributed to the book has allowed for the identification of chiastic patterns. However, as with other methods, these must be used carefully as 'There are many cross-references in the book of Ruth which do not fit into any of the sophisticated embracing schemes that have been proposed' (Korpel 2001:221). Illustrative of another complex approach is Bush (1996:33-36, 42), who refers to the abundance of devices like characterisation, dialogue and contrast. Bush also warns not to infer from the skilful style to conclude that it is not a historic narrative. Sasson, however, labels the literature genre of the book as a folk tale and Gunkel calls it a novella. Michael (2015:157ff.) shows how rhetorical questions and emotional terminology like 'my daughter, cry, embrace' play an important role. Satterthwaite (2011:123-127) also shows how the absence of expected facts and the use of implicit comments by the narrator, or the holding back of information can be used effectively adding to the intrigue and drama of the narrative.

Repetitions and structuring form an important part of the writer's emphasis on Naomi.

Firstly, her name is used prominently. Apart from the many references to her as 'mother-in-law', she is mentioned by name in Ruth 1 (8 times), in chapter 2 (5 times), in Chapter 3 ( 1 time) and in Chapter 4 ( 5 times). There is also an intended wordplay on the meaning of her name as 'pleasant' in 1:20:

"“Don't call me Naomi," she told them, "Call me Mara,

4.We are greatly indebted to the collective thinking and discussions of the Ruth Study Group ICassius Ribero, Group Cassius Ribeiro, Fabiano Fernandes, Hermanus Taute, Jose Henriques Rodrigues, Mathew Watson, Moisés Amado, Paulo d'Oliveira, Samuel Rodrigues, Cassius Ribeiro, as well as the lecturers and students of the Portuguese Bible Institute; 2012-2015; Unpublished notes of the Associação Evangélica de Educação - Instituto Bíblico Português in Tojal.) because the Almighty has made my life very bitter"' (New International Version ${ }^{\circledR}$ Anglicised [NIB]). Mara meaning 'bitter'. A testimony that the pleasantness or sweetness of her name does not apply to her life and circumstances any longer. No longer a wife, but widow; no longer a mother, but childless; she used to be full, but now empty. The name change expresses her judgement of circumstances.

Secondly, Naomi is presented as the main speaker in Ruth 1. After the historical introduction by the author (Rt 1:1-6) sketching her dire circumstances, becoming a widow in a foreign country, Naomi becomes the main speaker in three verbal exchanges with her two daughters-in-law, Orpah and Ruth.

The realisation that 'I am empty' (Rt 1:21), appears significantly in Naomi's confused state of mind. It may be asked whether this reflects a mindset that all must go well with God's people and the opposite is the cause of his judgement and reminiscent of the mistakes of Job's comforters. James (2008:58-59) explores this emptiness from the standpoint of a woman at a loss, relative to her personal standing and standing in society. This view must, however, be supplemented by the fact that the word rêqām [empty] is not an adjective but an adverb suggestive of containing nothing of relevance. Naomi knew that hesed and mānôah [rest] are obtained through Yahweh. That would be the expectation for continued sojourn in Moab, the expectations of remarriage of her daughters-in-law. This constituted the central focus of her first two speeches (Figure 1). But Naomi did not have such expectations for a return to Bethlehem. It would rather be a case of Yahweh-against-me.

Ruth interjects, enough is enough! With a series of double assertions, Ruth effectively silences her mother-in-law. Ruth shows the way by emphasising in the middle of her final answer, 'your God is my God, your people are my people!' She is willing to be a part of the real hesed and mannôh that the living God of Israel gives to and through his people. History corroborates her faith in Yahweh and allows for a richer understanding of both mānôah and hesed.

Rest (menûhâh/ mānôah) in the book of Ruth (1:9; 3:1), very concretely refers to security and basic stability. In Israel, this is always associated with the promises of God and Israel's promised heritage, the land of Canaan as promised to Abraham (Dt 12:8-11a). Angel $(2005: 98,99)$ compares Ruth to Abraham, leaving her birthplace for the land God indicates and becoming a blessing to the nations. In Chapter 1 and 3:1 Naomi seems to think that she possibly can provide or organise the rest that Ruth needs. It can only be partly true, as Hubbard (1997:1156) states: 'the book teaches that sometimes Yahweh's sovereign control comes secretly cloaked in human run events'. The constant interplay between human and divine initiatives is a strong focus in Prinsloo (1982).

Hesed, according to Hubbard (1997:1156), represents 'a lifestyle of loyalty, devotion and kindness that is God-pleasing' 


\begin{tabular}{|c|c|c|c|}
\hline Ruth 1 & Ruth 2 & Ruth 3 & Ruth 4 \\
\hline From Bethlehem to Moab & Bethlehem & Bethlehem & Bethlehem \\
\hline \multirow[t]{2}{*}{$\begin{array}{l}1: 1-6 \\
\text { Introduction on Naomi's } \\
\text { tragedy }\end{array}$} & $\begin{array}{l}2: 1 \\
\text { Introduction on Boaz, family of Naomi }\end{array}$ & $\begin{array}{l}3: 1,2 \\
\text { Naomi: 'My daughter, I will get you } \\
\text { rest and well-being'. }\end{array}$ & \multirow[t]{2}{*}{$\begin{array}{l}4: 1,2 \\
\text { Boaz summons elders and So-and-so } \\
\text { to sit at the gate }\end{array}$} \\
\hline & $\begin{array}{l}2: 2 \\
\text { Ruth - 'let me go and...'; } \\
\text { Naomi - 'go my daughter' }\end{array}$ & $\begin{array}{l}\text { 3:3-5 } \\
\text { Naomi - 'Go to Boaz' (10 orders); } \\
\text { Ruth: 'I will do...' }\end{array}$ & \\
\hline From Moab to Bethlehem & Fields of Boaz & Fields of Boaz & Bethlehem's gate \\
\hline $\begin{array}{l}\text { 1:7-10 } \\
\text { Naomi - 'daughters: go back' }\end{array}$ & $\begin{array}{l}2: 8-10 \\
\text { Boaz - Ruth }\end{array}$ & $\begin{array}{l}3: 7-9 \\
\text { Boaz-Ruth }\end{array}$ & $\begin{array}{l}4: 3,4 \\
\text { Boaz-So-and-so }\end{array}$ \\
\hline $\begin{array}{l}\text { 1:11-14 } \\
\text { Naomi - 'daughters: go back; } \\
\text { Yahweh is against me'. }\end{array}$ & $\begin{array}{l}2: 11-13 \\
\text { Boaz - Ruth }\end{array}$ & $\begin{array}{l}\text { 3:10-13 } \\
\text { Boaz - Ruth }\end{array}$ & $\begin{array}{l}4: 5-8 \\
\text { Boaz-So-and-so }\end{array}$ \\
\hline $\begin{array}{l}\text { 1:15-18 } \\
\text { Naomi - 'daughter: go back' }\end{array}$ & Boaz-Ruth & $\begin{array}{l}\text { 3:14-15 } \\
\text { Boaz - Ruth }\end{array}$ & $\begin{array}{l}\text { 4:9-12 } \\
\text { Boaz - elders and people }\end{array}$ \\
\hline Back in Bethlehem & Back in Bethlehem & Back in Bethlehem & Bethlehem \\
\hline \multirow{3}{*}{$\begin{array}{l}\text { 1:19-22 } \\
\text { Town's women: 'Is this Naomi?' } \\
\text { Naomi: ‘No, Mara... I came } \\
\text { back empty; } \\
\text { Yahweh is against me'. }\end{array}$} & $\begin{array}{l}2: 19 \\
\text { Naomi: 'Where? } \\
\text { Blessed be he ...' } \\
\text { Ruth: 'Name is Boaz' }\end{array}$ & $\begin{array}{l}\text { 3:16 } \\
\text { Naomi: ‘How/Who are you?’ }\end{array}$ & $\begin{array}{l}\text { 4:13-15 } \\
\text { Baby is born } \\
\text { Town's women: praise Yahweh, boy redeemer } \\
\text { and Ruth }\end{array}$ \\
\hline & $\begin{array}{l}\text { 2:20 } \\
\text { Naomi: 'Blessed be he ... redeemer' }\end{array}$ & \multirow{2}{*}{$\begin{array}{l}3: 17,18 \\
\text { Ruth: 'he said ... so that mother-in-law } \\
\text { not be empty'. } \\
\text { Naomi: 'sit ... he will not rest ...' }\end{array}$} & $\begin{array}{l}4: 16 \\
\text { Naomi receives the baby in silence }\end{array}$ \\
\hline & $\begin{array}{l}2: 21,22 \\
\text { Ruth: 'stay with my workers (m)'; } \\
\text { Naomi: 'rather with his female workers' }\end{array}$ & & $\begin{array}{l}4: 17-22 \\
\text { Town's women: 'a baby was born to Naomi' } \\
\text { They named him Obed. Perez to David genealogy. }\end{array}$ \\
\hline
\end{tabular}

Note: Naomi-conversations are highlighted.

FIGURE 1: Literary positioning of Naomi in the overall structure of the book of Ruth

and 'requires radical, loyal commitment to others'. It also entails 'the taking of great risks' such as when Ruth, as a stranger, had to venture into the fields and labour among unknown workers. Then the further risk of being misunderstood in the middle of the night at the threshing floor. It reflects doing things in the right way such as when Boaz did not take advantage of Ruth's vulnerability on the threshing floor but instead undertook to pursue the legal way to marry Ruth. This reflects practising hesed. Boaz's live and testimony affirms that Yahweh is the ultimate perfect paradigm of hesed $(2: 11,12)$.

Baer and Gordon (1997:211-218) highlight the fact that 'hesed is based on God's covenantal relationship with His people'. It is more valued by God than sacrifice (Mi 6:8) and those practising hesed certainly meet with his approval. That is why Boaz and Ruth are honoured by Naomi, the elders and the women of Bethlehem and God's people through the ages.

In Chapter 2, compared to Chapter 1, Naomi is not featured as the main speaker. The three centre dialogues belong to Boaz and Ruth. However, the beginning and the end of this chapter is framed with Naomi-dialogues. When Ruth declared her intention to go to look for 'grace in someone's eyes', Naomi only answers: 'Go my daughter'. When Ruth arrives with an efah ('êpâ) of grain, Naomi asks, "êpōh?', 'where' did you work? Immediately, she continues and pronounces a blessing of Yahweh on the man who did not 'leave behind his loyal covenant love' (hesed). Suddenly it is revealed that she knows Boaz, or of him and his covenantal relationship to her - he is a kinsman-redeemer $\left(g \bar{o}^{\prime} \hat{e} l\right)$ within her family. When Ruth relates the words of Boaz that she should stick with his workers (masculine), Naomi cautions Ruth with feminine forethought 'It will be good for you, my daughter, to go with the women who work for him ...' (Rt 2:22 NIB).

In Ruth 3, it is again Boaz and Ruth who take centre-stage with their conversations. However, it begins and ends with Naomi talking to Ruth. Naomi briefly regains some of her stature seen in Chapter 1 when she tells her daughters-in-law what to do. Three times she admonishes them to return.

She waits till the end of the barley season; then with 10 imperatives, instructs Ruth how to get Boaz inclined to marry her. As in Chapter 2, Ruth complies with Naomi's counsel. The chapter closes in similar fashion as the previous one with a question by Naomi: 'How did it go, my daughter?' (Rt 3:16 NIB) or literally, 'who are you ...?' ('How do you name or see yourself now?') (Waltke 2007:111). Again, with the last words of the chapter comes a final word of advice: 'Then Naomi said, "Wait, my daughter, until you find out what happens. For the man will not rest until the matter is settled today"' (Rt 3:18 NIB). Ruth was sent to find rest (Rt 3:1) and did so. However, can it be that the real focus is Naomi's rest? Tucked in between Naomi's remarks, Ruth relates what Boaz said, but not as the story was narrated above: 'He gave me these six measures of barley, saying, "Don't go back to your mother-in-law empty-handed."' (Rt 3:17 NIB). In Ruth 1:21, Naomi accused Yahweh, Shaddai, that she came back empty (rêqām) and in 1:22 she interplays the two names of God she is familiar with, Shaddai and Yahweh. A subtle nuanced shift 
in her complaint is that the Covenant God has turned against her. Her new name serves as a protest and she broadcasts that (Queen-Sutherland 2016:76). Yet, covertly or at least possibly unintentionally as the growing interplay of Boaz and Ruth's relationship may also have served mimetically to reflect Naomi's relationship with God. In a powerful way it seems to demonstrate Boaz's generosity in direct contrast to Naomi's lament. A lament the reader soon concludes that is being addressed. It might even be conjectured that the one 'êpâ that Ruth brought back, probably about seven weeks earlier than mentioned in Ruth 2:17, when added to the more recent six measures (3:17), graphically illustrate the intentional fullness of God's provision for Naomi (Stone 2013:189-199).

Chapter 4 emphasises the resolution of Naomi's problem. The narrative does not give the main speaker of Chapter 1 any chance to speak. No planning, no advice, no orders, not a word from Naomi is recorded. She quietly receives the baby, born in Bethlehem, to Boaz and Ruth. Naomi is finally fully filled. She will not answer to Mara anymore. Vastly different from Chapter 1, there is no 'don't call me Naomi, call me Mara' - only quiet satisfaction, fullness and rest. In addition, she hears the women (Rt 4:15) sing about her daughter-inlaw who is more valuable to her than seven sons!

To conclude - in the book of Ruth, a focus on Naomi is a valid perspective with substantial internal support by the author. The discussion will now proceed to show in more specific detail how and why Naomi is emphasised throughout the book.

\section{Naomi, as featured in the book of Ruth}

\section{A displaced Naomi changes into Mara:} A transition from fullness to bitterness

The irony of Bethlehem ('house of bread') being without bread is the first clue, revealing Naomi's trauma, the testing of her faith and adding to the confusion of how to take leave of her two daughters-in-law. The loss of her husband and two sons leaves her with a total sense of emptiness and an apparent inability to see Yahweh's provision and promises regarding Canaan - the land of God's promise known for its imagery of provision as the land of milk and honey (Ex 3:17). Her very real sorrow and bereavement, having suffered loss physically and emotionally inevitably affect her spiritual relationship with Yahweh. This is illustrated in different ways.

Firstly, after she loses her husband and two sons in Moab, Naomi, with great conviction, urges her two daughters-inlaw to return to Moab where they will find 'rest', because there Yahweh will give them Moabite husbands (Rt 1:8, 9). How can she think of Moab as the blessed place? But the story is also more personal. These two Moabite wives brought hesed into her life and the lives of her sons. But this does not feature in her lament at the end of her journey back to Bethlehem. There she blames Yahweh for making life bitter, removing all the sweetness of living. Wardlaw (2015:39), however, looks at the broader picture which must pose a problem for the reader. Moab is a land cursed by God, a constant temptation luring Israelites to their god, Baal Peor; although in the time of Ruth, there seems to have been free travel to Moab and back (Lund 1997:944-946). In addition, if there had been grandsons born to Naomi, they would not be able to enter the temple for 10 generations (Dt 23:3-6; Num 22-24; 25:1-3, 9; 31:8, 16; Jude 11). Clearly, the hesed enjoyed from God was to be seen at a more personal than at a national level.

Secondly, this confusion of where the blessing of Yahweh can be found, is further highlighted by the inclusion around the chapter: 'went from Bethlehem to Moab' (Rt 1:1) and 'went back from Moab to Bethlehem' (v. 22). It is interesting to note that the beginning and ending letters of both places are also the same but in inverted order: B-m ... M-b ... M-b ... B-m. Each destination is used five times as if they were destinations of equal choice. That is until the word return ( $\check{s} w b)$ is explored. It is used 12 times in the first chapter, turning it into one of the main key words and pointing to Bethlehem as God's choice for the confused Naomi and her daughters-in-law. Returning to Bethlehem was important, but more so, it implied returning to Yahweh, the provider of bread in Bethlehem.

Thirdly, Shaddai, meaning the 'One that is sufficient' (Braymer 1987:126-131; Bush 1996:33, 63, 92; Wenham 1994:20), is accused of being against her and leaving her empty. Clearly this is diametrically opposed to any theology focus on Shaddai. It simply does not make sense. QueenSutherland (2016:44) reminds the reader of the historical context of the book of Ruth as it was 'in the days when judges ruled'. A period of relative lawlessness and no safe place for women who were demanded to be productive and fertile (cf. Jdg 19:1). Wardlow $(2015: 37,38)$ concludes that the name El Shaddai is always associated with God's protection and covenant blessings of sufficiency. In effect, Naomi is accusing Yahweh of not keeping his covenant promises.

This point is also emphasised by the repeated use of the 'fields of Moab' (śedey mô'ā $b$ ) as opposed to Shaddai of Bethlehem. In Hebrew the slightly unusual spelling used here, appears to be the same (šadday 'שד) and 'fields of' (śedey (שi)). In the rest of the historical books, whenever Moab is mentioned, it is referred to as 'in the land' ( $b^{e}$ ereș) of Moab, or 'in the plains' (béarbôt) of Moab, or the 'desert' (midbā $r$ ) of Moab. In Ruth 1, a subtle contrast using these two similar words (šadday and śedey) develops a nuance to show Naomi's existing trauma clouding her perception of God.

The structure of Ruth 1 clearly reveals Naomi's most serious problem: her distorted interpretation of Yahweh's dealings with her (Figure 3).

To sum up - Yahweh's involvement in Naomi's suffering is referred to in the beginning, middle and end of the chiastic 
rhetorical structure. It is the darkest time in Naomi's life and in her extreme bitterness, she seems unable to see any positive sign of the All Sufficient (El Shaddai) and the Active, Present and Faithful (Yahweh), Lord of the Covenant. She consequently concludes subjectively against God. The story may well have ended right there if it had not been for Ruth's living faith commitment to Naomi and to her God. Naomi could have returned to Bethlehem alone, and without the greatest blessing from Yahweh - a 'daughter' like Ruth.

\section{Bitter Mara and Ruth: Surviving resettlement through circumstantial provision}

In Ruth 1 the traumatic depths of bitterness and Naomi's struggle with Shaddai is exposed. The sweet and pleasant 'Naomi' feels under attack from God.

The structure of Ruth 2 seems to be the same as Ruth 1's - it contains three dialogues in the middle, but this time the conversation is between Ruth and Boaz (see Figure 2).

At the outset after her return to Bethlehem, Naomi seems to be subdued. She is not overly enthusiastic when Ruth asked if she might go to see what grace she could find, referring mainly to food. Only at the end of the chapter, Naomi shows some reaction when she recognises and blesses the man that maintained and did not lose his hesed - his faithful covenant love. In sharp contrast with Naomi, passive and unable to summon energy in the sapping struggle of her state of bitterness, are the actions and faith conversations of Boaz and Ruth.

The believing Ruth, who confessed the God of Israel and of Naomi, takes the initiative to go and 'find grace in someone's eyes' (Rt 2:2). This phrase is repeated twice in the dialogues between Boaz and Ruth $(2: 10,13)$. It is linked with the verb $n \overline{\mathrm{e}} \mathrm{k} \overline{\mathrm{a}} r$, meaning 'to notice', which enforces the expression 'find grace in someone's eyes'. To see and to take notice are the first steps of showing grace in this narrative. This is further emphasised in the interesting wordplay. A foreigner is called nŏkrî. To 'notice me, and I am a foreigner' is expressed as: hakirenîy 'anokîy nŏkrîyāh (Rt 2:10-New English Translation Bible [NET] notes). The point is that it also emphasises an active way of deliberate looking.

Boaz's answer to Ruth's appreciation, turns the focus away from himself to Yahweh, God of Israel. This is reminiscent of the middle dialogue of Ruth 1, where Naomi said: 'Yahweh's hand turned against $\mathrm{me}^{\prime}$. Contrasting that statement in the middle dialogue of Ruth 2, Boaz says: 'May you be richly rewarded by the LORD, the God of Israel, under whose wings you have come to take refuge' (v. 12 NIB).

The reader is beginning to get some indication that Yahweh is in the process of healing Naomi's bitterness and emptiness. This comes about through God allowing her to recall his ways with his people, and the example of Boaz and Ruth seems to fit into those ways. Naomi is gradually learning to trust the Covenant God and his ways once again, and to do so by faith. She takes refuge under God's wings (a metaphor

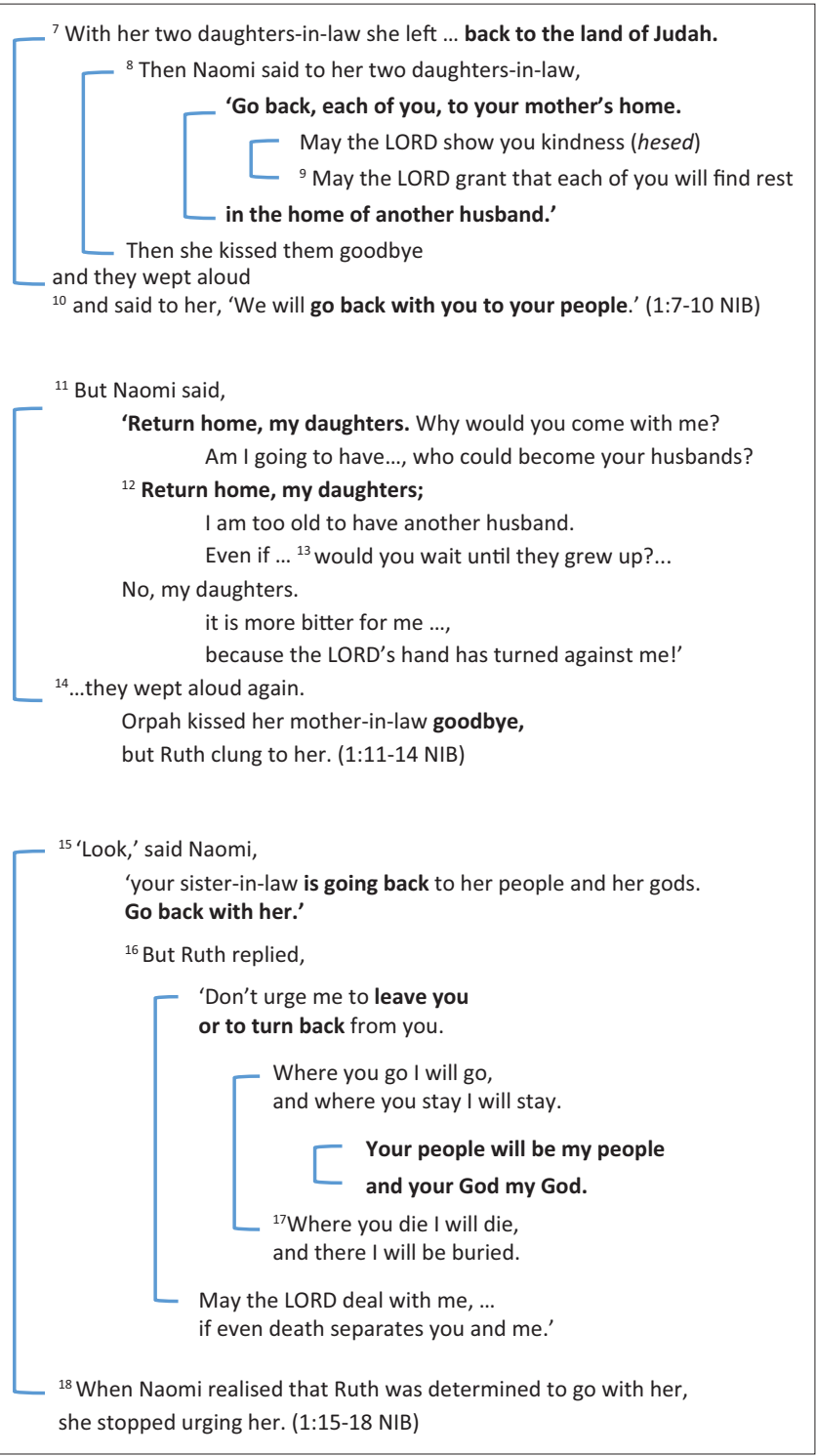

FIGURE 2: The rhetorical structure of Naomi's three attempts to send back her daughters-in-law to their gods and people - revealing her confused thinking (first two conversations), in contrast with Ruth's clear focus on God, Naomi's welfare and certainty about her commitments (third conversation)

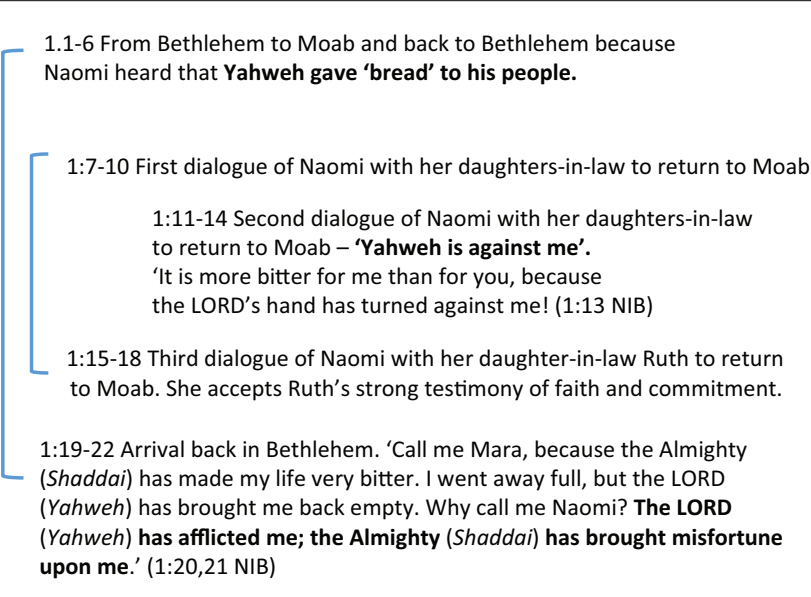

FIGURE 3: Chiastic structure of Ruth 1, emphasising Naomi's confusion that God is against her, in the beginning, middle and end of the structure. 
for his covenantal protection). As with Ruth, she will be rewarded (literally 'filled up' [šălèm]) (Rt 2:12), her bitterness dissipated.

Both Ruth and Boaz are important to Naomi. Their sense of responsibility made them useful instruments in the hands of the Lord (Luter \& Rigsby 1993:57). In the case of Boaz, he is prepared to do more than the minimum requirements of the law (Lv 19:9, 10; 23:22; Dt 24:19-22). Apart from being willing to raise a descendant for Elimelech by marrying Ruth, he also adheres to the Torah in looking after the poor and widows (Block 2017:117). Boaz does this by letting them glean in his fields. He does the same and more than what was required for strangers, remembering Israel's time as strangers and slaves in Egypt (Dt 10:17-19).

The air is loaded with suspense when Ruth arrives home at the end of her first day. When Naomi 'saw' what she brought home, it became evident that Ruth had found someone who noticed her with grace in his heart. Naomi takes some of the roasted grain Ruth saved from lunch, as she must have been very hungry (Rt 2:18). Only then does the author reveal their conversation recording a wordplay on the one ephah. Naomi asks 'êpâh? [where?] (Rt 2:19). Then she blesses the man who took notice (nēkār) of Ruth. After hearing his name, Naomi blesses him again and sings the praises of Boaz who did not leave his hesed behind, referring to the man's kindness shown so abundantly to Ruth (2:20).

\section{Conclusion}

Two totally unexpected blessings come from the lips of 'don't call me Naomi but Mara!' The embittered Naomi is changing. For the first time, Naomi says something positive about Yahweh and his work through people who don't leave their hesed behind; people who take refuge under God's wing; people who take notice and help those in need.

\section{From uncertainty to kinsman trust and rest}

Ruth 3 begins with Naomi getting into action mode taking control. 'My daughter, will I not find rest for you, that it may be well with you?' (v. 1)

With 10 imperatives, Ruth is given detailed orders. The verb șiwwattāh [to order] emerges from the noun mișwāh, [commandment] and confirms the seriousness of Naomi's plans (Rt 3:6). It entailed every possibility of compromising Ruth and embarrassing Boaz. These instructions serve to steer Ruth to the point where she commits herself to a position of lying down beside Boaz - one of the family kinsmanredeemers. It was an all-or-nothing strategy on which Naomi, alias Mara, stakes everything. The plan unfolds step by step. All is done quietly and in secret, nuanced by the word ballat associating the subtle playing out of the drama. This places Ruth in a very vulnerable situation. Contrary to the opinion that Naomi's only concern was to find an heir for her deceased son, the text emphasises that Naomi wants to provide 'rest' for Ruth, meaning her general well-being.

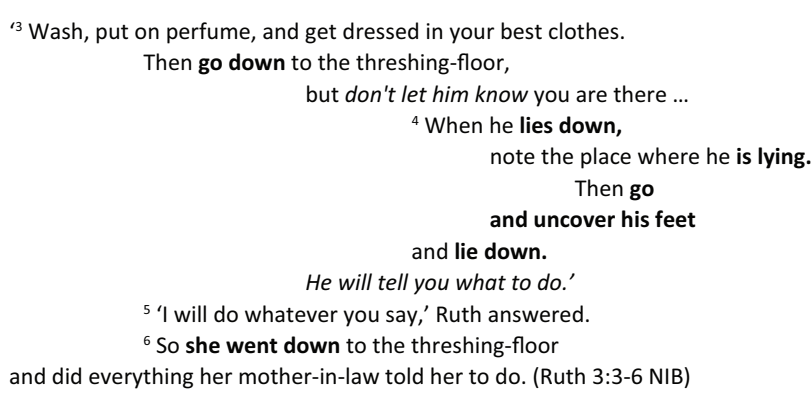

FIGURE 4: Naomi apparently recovered enough to take the lead again and with detailed and structured imperatives makes sure that Ruth will do the necessary to achieve her goal.

Her detailed plan is orderly arranged in an inverted structure (Figure 4), emphasising 'go down, lying down' and 'go, uncover his feet'. With plans in place, Ruth executes them. But for the first time, Ruth does not follow Naomi's advice to the letter, namely that Boaz should now take charge. Instead, she tells Boaz what to do, reminiscent of Boaz's prayer for her protection upon their first meeting in his fields (Rt 2:12) calling upon 'the God of Israel, under whose wings you have come to take refuge'. Following up on that prayer, Ruth asks from Boaz what he asked God for on her behalf, 'Spread the corner of your garment over me, since you are a guardianredeemer ${ }^{5}$ of our family' (Rt 3:9 NIB); a powerful metaphor for protection. This is one that can be used to make sense of the subtle tensions and nuances between Boaz and Ruth's present and previous encounters (Rt 2:12b). Ezekiel 16:8-12 depicts a situation with some similarity in which Yahweh covers the naked Jerusalem with the corner of his garment and marries her (Bush 1996:151; Queen-Sutherland 2016:122). In other words, it may be reasonably argued that Ruth effectively asked Boaz to marry her!

Hamilton (2011:361) explains the background of Deuteronomy 32:11 where the eagle's wings describe the extraordinary love of God towards his people. Cansdale (2008:69) further qualifies the meaning by explaining that both eagle and vulture were considered to be symbols of power in Egypt, explaining the use of the metaphor in Exodus 19:4: 'You yourselves have seen what I did to Egypt, and how I carried you on eagles' wings and brought you to myself'. (NIB) The last words, however, bring in the dimension of marriage and covenantal unity. '... brought you to myself' is a technical term for marriage (NET).

In Ruth 2:10, the emphasis and meaning of taking refuge under the wings of Yahweh leans towards God's, and by implication his servant Boaz's capacity of giving protection to Ruth and Naomi. The same idea is found in Psalm 91:4 where God spreads his protective wings over the just, as well as in the words of Jesus (Mt 23.37; Lk 13.34; Domeris 2011:254, 256).

As in Ruth 1 and 2, we find three dialogues in the middle section of Ruth 3. The middle dialogue is also emphasised, because it starts and ends with references to Yahweh (Rt 3:10, 11), with Boaz blessing Ruth for her greater faithful 
love (hesed), and being a 'worthy woman' ('ešet hayil). Ruth and Naomi entered into a man's world on the threshing floor, but now both she and Naomi are covered by the commitment of Boaz, who called on Yahweh to be his witness, if the other redeemer will not, 'I will do it' (Rt 3:13).

The chapter ends with Naomi telling Ruth to exercise restraint. She is not to go, nor to lie down, but to sit and wait. Naomi submits control of the situation to covenantal promises. Boaz will solve whatever there is left to resolve.

\section{Conclusion}

Naomi can trust again in the God of the covenant, in the structures of care like the kinsmen-redeemers among the people of the Covenant and in his faithful servants like Boaz and Ruth.

\section{Boaz, the bargaining redeemer, filling up Naomi's emptiness, under the wings of Yahweh}

In Ruth 4 the activity is centred on Boaz (vv. 4:1-2 and 13-16). He does the organising and meeting with the more immediate kinsman-redeemer. Boaz does the talking, steering the conversation strategically. All this is recorded in the now familiar pattern of three dialogues in the middle section of the chapter. This time, however, the dialogues are not arranged symmetrically, but in parallel fashion, making the third one the climax of the conversations. The third dialogue itself shows an inverted order, starting with the 'elders and the people' and ending with the 'people and the elders' (Figure 5).

From the above it is evident that twice the elders and the people are called 'to be witnesses' ('ûd), or legally attest the proceedings. There is a case to be made here for an intentional double meaning, 'bear witness or return', in which case the author would want us to link this witness with šwb [return], an important factor referring back to the recorded narrative in Ruth 1. A witness 'repeats' or 'returns to say' (Harris, Archer \& Waltke 1980:1082-1083). The repetition of 'today you are witnesses' calls to mind the last words Naomi spoke:

${ }^{9}$ Then Boaz announced to the elders and all the people,

'Today you are witnesses that I have bought from Naomi all the property of Elimelek, Kilion and Mahlon.

${ }^{10}$ I have also acquired Ruth the Moabite, Mahlon's widow, as my wife, in order to maintain the name of the dead with his property, so that his name will not disappear from among his family or from his home town.

Today you are witnesses!'

${ }^{11}$ Then all the people at the gate and the elders said, (Hebrew word order) 'We are witnesses.

May the LORD make the woman who is coming into your home like Rachel and Leah, who together built up the family of Israel. May you have standing in Ephrathah and be famous in Bethlehem.

${ }^{12}$ Through the offspring the LORD gives you by this young woman, may your family be like that of Perez, whom Tamar bore to Judah.'(NIB)

FIGURE 5: Boaz made sure that his marriage with Ruth is approved and legal, properly witnessed. The people and the elders go further, praying for God's continued up building of his people through this special marriage, under God's wing.
'For the man will not rest until the matter is settled today' (Rt 3:18 NIB; Hubbard 2008:343). Naomi does not speak in Ruth 4, but the import of her previous words supports the development of the public proceedings.

The next section mirrors Boaz's action (Rt 4:1,2), in the most public manner possible, convening the meeting at the gate. Boaz does not offer his customary blessing of Yahweh to the nearer go'êl whom he does not even call by name, but as peloni 'almoni, meaning 'So-and-so'. Naomi, a widow, is tied to the land on sale. Her husband, Elimelech, and his heir, Mahlon, were deceased, but his widow, Ruth, was alone. Ruth was still of childbearing age and her son would legally inherit the land from the kinsman-redeemer. Clearly Naomi was no threat to the nearer kinsman-redeemer, but Ruth was. Whatever decision is made about the field in question, the socio-cultural norms of the time dictated that Ruth was included and a levirate marriage was expected. It was both a social responsibility and divine providence (Ames 2011:457). When matters were concluded, Boaz as the nearer redeemer, accepts the declined right to redeem Ruth. The wedding is filled with acclamations and blessings of the women of Bethlehem and the story concludes for Naomi who now has a son named Obed (4:13-16).

Yahweh intervenes twice, according to the narrative. Once by giving bread in Bethlehem (Rt 1:6), an action that prompted Naomi's return, and a second time through direct intervention causing Ruth to conceive. ${ }^{6}$ Finally filled, as 'Naomi took the child, and laid him in her lap and cared for $\operatorname{him}^{\prime}(4: 13)$.

Naomi, this time round does not respond the way she did in Ruth 1:19-21. There she gave Yahweh all the blame, emphasised by the inverted order of Shaddai ... Yahweh ... Yahweh ... Shaddai (Figure 6).

However, in this final chapter of the book, there is a pregnant silence. There is no outburst from Naomi in answer to the town's women's joy and praise. Her reply is her silence.

One reason can be that she had to reconsider her previous utterances about Yahweh. After all, it was by his intervention that the baby was born. What can she say? Reasonably put, she has learned to trust God again.

A second reason for her silence can be that she also had to reconsider her continued persuasions trying to force Ruth to return to Moab, a place where she might find rest and Yahweh's blessing (Rt 1:8, 9). Now she doesn't oppose the women praising Ruth as the one who loves her - love as expressed by partakers in covenant with God. However, she may have considered the biggest gift a woman can hope for: a daughter-in-law 'more valuable than seven sons' (Rt 4.15; Block 1999:729-730). Naomi could now discern God's hand in her Moabite believing daughter-in-law.

6.Bovell (2003:180) links the two interventions of Yahweh to explain how the problem of 'not having a king' (Rt 1:1,6) is solved by the bread from above, the davidic son, born in Bethlehem. 


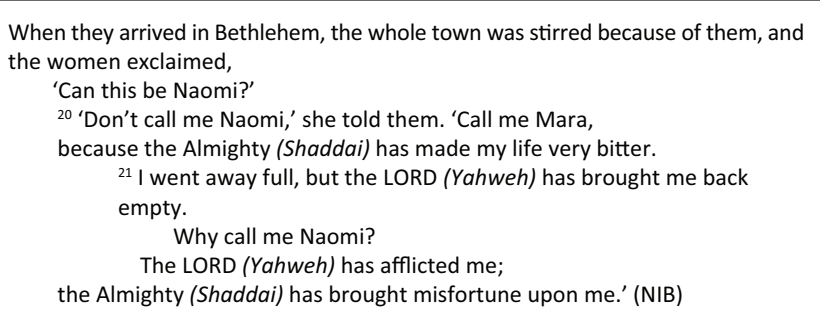

FIGURE 6: Naomi's reply to the women in Chapter 1 emphasised her disillusion with the Covenant God by repeating consecutively his covenant names in chiastic order, Shaddai - Yahweh - Yahweh - Shaddai.

Naomi, alias Mara, found grace in the provision of her kinsman and daughter-in-law. Hubbard (2008:361) understands the list of benefits the new go' $\mathrm{e} l$ will bring to her life, not as wishes, but as promises. There might be another wordplay $^{7}$ calling attention to šwb [turn back], the main keyword of Ruth 1, used 12 times. In Ruth 4:15, we have mêsib, sibatekāh and missebāh. Mêsib (Hifil participle of šwb) nepeš, meaning 'he made my life return' (Rt 4:15), may then be seen as the follow-up of hfšibani (Hifil perfect of šwb) rêqām, meaning 'He brought me back empty' in Ruth 1:21. Incidentally, these are the only times šwb appears in the Hifil form in the book of Ruth. The meaning would then be found in the semantic range of 'he gave me back my vitality' - 'he comforts me, fills my emptiness up' - 'he makes it possible that the lineage continues'. That is the grace of God, allowing a hard-hit covenant family to become whole again as they turn back to Bethlehem and El Shaddai.

In Ruth 1:11 Naomi says: 'return and go back my daughters' (šobnâh benotay) which also creates a contrast through sound and meaning with 4:15: 'she is better than seven sons' (mišivāh banim) and 'he will turn around and renew your life' (lemešiv nepeš). The rhetorical structure (see Figure 7) links 'the Lord enabled her to conceive' (13b), with 'who is better to you than seven sons' (15d).

We can safely say that the multiple literary techniques used by the author of Ruth, help us focus on God's intervention attending to the bitter trauma of Naomi. God uses Boaz, he uses Ruth and he uses a baby born in Bethlehem to bring the reader full circle back to the new life and rest only he can provide.

As Block (1999:612) remarks, apart from God's providential control, the author has the goal of showing how true covenant faith and hesed look, always showing concern for the welfare of others.

A third reason to consider is that of her emptiness in losing her two 'babies'. This unusual term for the loss of her two married sons, namely 'her little children' (yelādeyhā) $)^{8}$ is used in 1:5. This description is repeated in Ruth 4:16 when 'Naomi

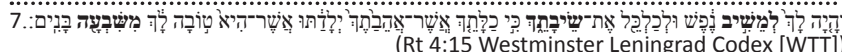

8.'This is the only instance where yeled is used for married men. Elsewhere it connotes "infant" (Gn 21:18; Ex 2:3; 2 Sm 12:15), "teenager" (Gn 37:30; 42.22; possibly 2 K 4:1), and "young man" (versus "elders", 1 Ki 12:8 $=2$ Chr 10:8)' (Hubbard 1988:96 as quoted in Bovell 2003:180).

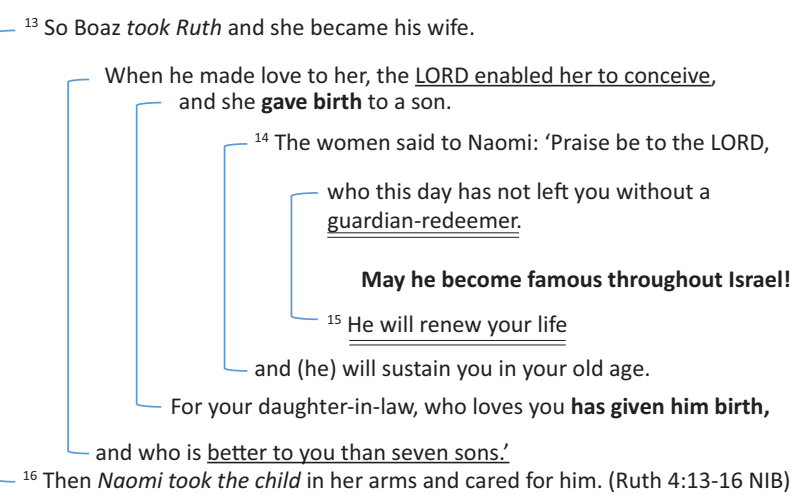

May he become famous throughout Israel! ${ }^{5} \mathrm{He}$ will renew your life

- and (he) will sustain you in your old age.

- For your daughter-in-law, who loves you has given him birth,

- and who is better to you than seven sons.'

${ }^{16}$ Then Naomi took the child in her arms and cared for him. (Ruth 4:13-16 NIB)

FIGURE 7: Eloquent summary of how Yahweh dealt with every aspect of Naomi's trauma and confusion. The middle portion emphasises the child as her guardian-redeemer, he will renew her life. The outer layers, 4.13, 15b, 16, emphasises the fact that this huge blessing comes from the Lord that intervened, through his servants Boaz and Ruth, a blessing that will echo throughout Israel's history (centre).

took the child (yeled) to her bosom'. This was exactly what she needed. Little Obed served Yahweh's purpose in restoring Naomi, his answer would 'renew her life' (Rt 4:14, 15). Naomi was truly filled.

A fourth implicit reason for Naomi's silence, we suspect is the increasing mention of the people of Yahweh who long and pray for the up building of the house of Israel (Rt 4:11). The elders at the gate associated Ruth with Rachel and Leah who built up the house of Israel into a nation. Queen-Sutherland (2016:158ff.) develops this association to suggest that God's history is unfolding with this event. Shaddai is sufficiently for history let alone for a stranger in a foreign land. The implication is that from this perspective, the requests and laments of an individual or nation at any given point in time are subservient to God's providential unfolding of history. More specifically, it is from within the historical context of ungodly chaos recorded in the book of Judges (21:25), that it becomes evident that God is steadily working out his plan to establish the eternal house of his servant David (2 Sm 7:15-19).

Naomi had every reason to be quiet and fulfil her role looking after her grandson, Obed. The baby would be a further instrument in the unfolding plan of God's purpose.

\section{Conclusion}

Naomi, who descended into bitterness is transformed into Naomi once again, a member of God's Covenant People. All the reasons for her trauma and confusing thoughts about herself, God and his way of working, have been or were in the process of being resolved. As Hubbard (2008:365) suggests, she exemplifies the believer who, through a living experience of the faithful presence of God, not only can overcome bitter traumas, but can find rest in the knowledge that she is a part of his plan and of the people that live to glorify him. But it must be said at once that nothing is said of Ruth's management of her own angst. As with Naomi, Ruth is also silent at the story's end, which is interpreted by feminist reader Honig (1999:72; cf. reference to Queen- 
Sutherland 2016:71) to signify Ruth's failure to establish any meaningful bond with the self-absorbed Naomi. But, as Korpel (2001:230) suggests, it all came together for Naomi, because God provided her with a redeemer (Rt 4:14). He even suggests that Naomi represents the old Zion and Ruth personifies the new Zion, the abused woman contrasted with the bride (Korpel 2001:231).

\section{From Naomi's blessed kinsman-redeemer to the serving Redeemer promised to mankind}

The book of Ruth does not end abruptly. It more than hints at the future. In the last chapter, 'people' appears three times, and 'Israel' five times. There is the prayer for the building up of the nation and that Ruth will be as Rachel and Leah, Jacob's wives and founding mothers of the 12 tribes of Israel! Tamar is mentioned as the Canaanite stranger that was refused a kinsman-redeemer by Judah, her father-in-law (Gn 38). However, providentially she eventually bore Judah's children, the twins, Perez and Zerah. The Perez-clan became the dominant clan to which the majority of witnessing crowd in Bethlehem belonged. Tamar was therefore fully accepted as a founding mother, likewise Ruth the Moabitess was also accepted much later (Hubbard 2008:347-348).

\section{A concluding but continuing genealogy}

No other book ends with a genealogy. For that reason, it calls for special attention. It is soon evident to the Old Testament reader, the genealogy of Ruth 4 continues to become the genealogy of King David and beyond him! It is probably no coincidence that 'redeemer' appears 14 times and 'giving birth' also 14 times. It reminds us of the promises regarding the House of David (the number value of David is 14), 2 Samuel 7:15-19 and why God's plan for the whole of mankind features through David and his ascendants and descendants. Elimelech [my God is King] died in Moab in Ruth 1, but through Boaz and Obed, the go'êl redeemers of Naomi, the significance of his name echoes in the powerful unfolding of the plan of God. He is building more than a people; God is building his kingdom, consisting of people from all the nations of the earth: men, women, young and old, Jews and gentiles.

Naomi found that Shaddai, the all-sufficiently God and Maker of Israel, filled her to the extent where she had no more to say. She received Obed and again could say no more.

In a tough world, there are many possibilities of families being torn apart through circumstances. Throughout history, like in the time of the Judges, people have rather believed in their own solutions than those that beckons on the horizon with El Shaddai. Those that put their trust in him, will not only be restored, but stand in silent awe and wonder before the God of Israel.

\section{Conclusion}

This article shows clearly that the book of Ruth is not only a story narrative about Ruth and a sullen Naomi. Nor is it a storyline to be exploited by feminist agendas as opposed to a traditional patriarchal interpretation. No doubt, these matters must be addressed, but the focus on Naomi highlights the recovery of her faith. A spiritual transformation came about for Naomi. Indeed, the three main characters of the narrative saw the playing out of God's purposes not only for their own lives, but within the greater plan, of salvation within the nation of Israel. Within that plan, Naomi was instrumental in Ruth's continuing the family line of Boaz within the tribe of Judah, the historical royal family line of David. Back under God's wings, Naomi become much more than just Naomi again.

\section{Acknowledgements}

Hermanus Taute acknowledges the shared input of the book of Ruth study group of the Instituto Bíblico Português, Portugal, which enriched his input in co-authoring this article with Raymond Potgieter.

\section{Competing interests}

The authors have declared that no competing interest exists.

\section{Authors' contributions}

R.P., Faculty of Theology, North-West University, South Africa. H.T., Faculty of Theology, North-West University, South Africa and Instituto Bíblico Português, Lisbon, Portugal. Both authors contributed equally to this article.

\section{Ethical consideration}

This article followed all ethical standards for a research without direct contact with human or animal subjects.

\section{Funding information}

This research received no specific grant from any funding agency in the public, commercial or not-for-profit sectors.

\section{Data availability statement}

Data sharing is not applicable to this article as no new data were created or analysed in this study.

\section{Disclaimer}

The views and opinions expressed in this article are those of the authors and do not necessarily reflect the official policy or position of any affiliated agency of the authors.

\section{References}

Ames, F.R., 2011, 'Casamento de levirato', in VanGemeren, W.A. (ed.), Novo Dicionário Internacional de Teologia e Exegese do Antigo Testamento, vol. 4, p. 456, Editora Cultura Cristã, São Paulo.

Angel, H., 2005, 'A midrashic view of Ruth: Amidst a sea of ambiguity', Jewish Bible Quarterly 33(2).

Baer, D.A. \& Gordon, R.P., 1997, דот (ḥsd II), in W.A. vanGemeren (ed.), Novo Dicionário Internacional de Teologia e Exegese do Antigo Testamento, vol. 2, pp. 209-216, Editora Cultura Cristã, São Paulo.

Block, D.I., 1999, 'Judges, Ruth', in D.S. Dockery (ed.), The New American Commentary, vol. 6, B\&H Publishing Group, Nashville, TN 
Block, D.I., 2005, 'Ruth: A discourse analysis of the Hebrew Bible', Zondervan, Grand Rapids, MI. (Zondervan Exegetical Commentary on the Old Testament).

Bovell, C., 2003, 'Symmetry, Ruth and canon', Journal for the Study of the Old Testament 28(2), 175-191. https://doi.org/10.1177/030908920302800203

Bräumer, H., 1987, 'Das erste Buch Mose', in G. Maier, A. Pohl (eds.), Wuppertaler Studienbibel, Brockhaus Verlag, Wuppertal.

Bush, F., 1996, 'Ruth, Esther', in D.A. Hubbard, G.W. Barker \& J.D.W. Watts (eds.), Word Biblical Commentary, Word Books, Publisher, Dallas, TX.

Cansdale, G.S., 2008, 'Asas', in C.T. Merrill (ed.), Enciclopédia da Bíblia, vol. 1, p. 533, Editora Cultura Cristã, São Paulo.

Domeris, W.R., 2011, '6114 סכך (skk)', in W.A. VanGemeren (ed.), Novo Dicionário Internacional de Teologia e Exegese do Antigo Testamento, vol. 3, p. 254, Editora Cultura Cristã, São Paulo.

Hamilton, V.P., 2011, '851 אשה ('iššâ)', in W. VanGemeren (ed.), Novo Dicionário Internacional de Teologia e Exegese do Antigo Testamento, vol. 1., p. 523, Editora Cultura Cristã, São Paulo.

Harris, R.L., Archer Jr., G.L. \& Waltke, B.K., 1998, '1576 עוּד ('ûd) voltar, repetir', in R. Malkomes (ed.), Dicionário Internacional de Teologia do Antigo Testamento, vol. 3 , Vida Nova, São Paulo.

Harrison, R.K., 2008, 'Moabe/Moabitas', in C.T. Merrill (ed.), Enciclopédia da Bíblia vol. 4, pp. 320-329, Editora Cultura Cristã, São Paulo.

Honig, B., 1999, 'Ruth, the model emigrée: Mourning and the symbolic politics of immigration', in A. Brenner (ed.), Ruth and Esther: A feminist companion to the Bible, pp. 50-74, Sheffield Academic Press, Sheffield.

Hubbard, Jr., R.L., 1988, The book of Ruth, Eerdmans, Grand Rapids, MI

Hubbard, Jr., R.L., 1991, 'Go'êl in Ancient Israel: Theological reflections on an Israelite Institution', Bulletin for Biblical Research 1(1991), 3-19.

Hubbard, Jr., R.L., 1997, 'Theology of Ruth', in W.A. VanGemeren (ed.), New International Dictionary of Old Testament Theology \& Exegesis, vol. 4, pp. 1153-1157, Zondervan, Grand Rapids, MI.

Hubbard, Jr., R.L., 2011a, 'Teologia de Rute', in W.A. VanGemeren, (ed.), Novo Dicionário Internacional de Teologia e Exegese do Antigo Testamento, vol. 4, p. 1142, Editora Cultura Cristã, São Paulo.
Hubbard, Jr., R.L., 2011b, 'Goel', in W.A. VanGemeren (ed.), Novo Dicionário Internacional de Teologia e Exegese do Antigo Testamento, vol. 1, p. 765, Editora Cultura Cristã, São Paulo.

Hubbard, Jr., R.L., 2008, Exposição de Rute, Editora Cultura Cristã, São Paulo.

James, C.C., 2008, The gospel of Ruth: Loving God enough to break the rules, Zondervan, Grand Rapids, MI. (Comentários do Antigo Testamento).

Korpel, M.C.A., 2001, The structure of the book of Ruth, Koninklijke van Gorcum, Assen.

Lund, J.A., 1997, 'Moab', in W.A. Van Gemeren (eds.), New International Dictionary of Old Testament Theology \& Exegesis, vol. 4, pp. 944-947, Zondervan, Grand Rapids, MI.

Luter, A.B. \& Rigsby, R.O., 1993, 'The Chiastic structure of Ruth 2', Bulletin for Biblical Research 3, 49-58.

Michael, M., 2015, 'The art of persuasion and The book of Ruth: Literary devices in the persuasive speeches of Ruth 1:6-18', Hebrew Studies 56, 145-162.

Prinsloo, W., 1982, Die boek Rut, NG Kerk-Uitgewers, Kaapstad.

Queen-Sutherland, K., 2016, 'Ruth and Esther', Smyth \& Helwys Publishing, Macon, (GA. Smyth \& Helwys Bible commentary).

Satterthwaite, P.E., 2011, 'Genealogias no AT', in W.A. VanGemeren (ed.), Novo Dicionário Internacional de Teologia e Exegese do Antigo Testamento, vol. 4. pp. 665-666, Editora Cultura Cristã, São Paulo.

Stone, T.T., 2013, 'Six measures of Barley: Seed symbolism in Ruth', Journal for the Study of the Old Testament 38(2), 189-199. https://doi.org/10.1177/0309089 213511755

VanGemeren, W.A., 2011, 'Vários exemplos de como integrar o Guia com o NDITEAT na elaboração da Exegese e da Teologia do Antigo Testamento' in W.A. VanGemeren (ed.), Novo Dicionário Internacional de Teologia e Exegese do Antigo Testamento, vol. 1, pp. 199-206, Editora Cultura Cristã, São Paulo.

Waltke, B.K., 2007, An Old Testament Theology: An exegetical, canonical and thematic approach, Zondervan, Grand Rapids, MI.

Wardlaw Jr., T.R., 2015, 'Shaddai, providence, and the narrative structure of Ruth', Journal of the Evangelical Theological Society (Jets), 58(1), 31-41.

Wenham, G.J., 1994, 'Genesis 16-50', in D. Hubbard, G.W. Barker \& J.D.W. Watts (eds.), Word Biblical Commentary, Word Books Publisher, Dallas, TX. 